\title{
Effect of Bioregulators on Chlorophyll Content at Matthiola incana and Scabiosa atropurpurea
}

\author{
Szilvia KISVARGA*, Ildikó KOHUT, Andrea TILLYNÉ MÁNDY \\ Department of Floriculture and Dendrology, Corvinus University of Budapest, H-1118, Budapest, \\ Villányi street 29.-43., Hungary \\ *)Corresponding author, e-mail: fullerina@gmail.com
}

BulletinUASVM Horticulture 73(1) / 2016

Print ISSN 1843-5254, Electronic ISSN 1843-5394

DOI:10.15835/buasvmcn-hort:11925

\begin{abstract}
During our experiment the effect of chlorocholine chloride, Caramba, Cultar, Regalis and Toprex bioregulators were examined on some annual ornamental species. The species used for the experiment were Coreopsis grandiflora, Godetia grandifolra, Scabiosa atropurpurea and Matthiola incana. The aim of this work was to produce marketable, bushy habitat annual plants as flowering pot plants with the use of retardants. The experiment was carried out from April to September 2013, plants were treated beweekly. It was found that all the treatments had effect on the plants but the result depended on the species. In the case of Coreopsis grandiflora the best dwarfing effect was obtained with Regalis $0,25 \%$ and Caramba at $0,05 \%$ concentration, the maximum shorten rate was $50 \%$. In the case of the other examined species intensive retardant effect was observed with the spray of Cultar, Toprex or Caramba. Best results were obtained by the treatment of Matthiola incana, all the chemicals resulted compact, bushy, decorative plant habitat, Regalis WG had the best results among the bioregulators. The chlorophyll content of two plant species was measured: Scabiosa atropurpurea and Matthiola incana. The chlorophyll content of the leaves was reduced by using growth retardants. The rate of decrease depended on the regulator type and the plant species. By cultivation for market is mandatory to do trial management before use.
\end{abstract}

Keywords: bioregulator, chlorophyll, Matthiola, Scabiosa, annual, pot plant, growth regulator

\section{INTRODUCTION}

Most of conducted experiments were in Germany and Britain at herbaceous and woody plants, too. Basra (2000) carried out valuable findings on agricultural and floricultural species, by these not only micro-and macronutrient supply, but also in terms of the use of bioregulators. Reiners (2007) examined the effects of daminozide active substance preparation potted ornamental plants Alar-85 and concluded that the treated plants show growth-property much better than by the control group. Treatments performed Richter (2006) Hydrangeas in concluding that regulate shoot growth of apple and pear authorized active substance treated with prohexadione-Ca and Regalis WG with plants are bushier, more marketable, but it is only capable of producing white flowers. Ueber established in 2007 during the experiments on Androsace semptentrionalis 'Star Dust' by domancy times variety for an appropriate time dormancy habits beautiful plants can be obtained. The same studies showed that the active ingredient metconazole Caramba, which allowed against diseases of cereals and canola fungicide and growth regulator specifically recommended, as active ingredient flurprimidor Topflor good mode of action. It was found that the only treatment for Regalis treated plants at a much lower height only, but the colour of these flowers were lighter, than the non-treated group of flowers.

By Ruttensperger and Koch (2005) Angelonia varieties were treated with chlor-choline chloride (CCC) effects, in terms of the number that is the height of the treated plants and branches of the results were compared to significant to the control 
group, although the plants treated with about two weeks later flowering produced.

By Băla Maria and D.N. Berecici (2009) Pelargonium species were treated because the effect of Cycogan on the flowering and growthing. The influence of Cycogan on Pelargonium zonale showed positive significant differences to the control group. During the researches, it was studied several literature that the retardant field assess the impact on plants.

Mansour et al (2010) for two consecutive years (2007 and 2008) examined whether could be a possible treatment for Helianthus annuus potted ornamental. Paclobutrazol significantly reduced the diameter of the flower and the plant dry matter content increased.

Measurements were also made in which various horticultural crops regarding joint were analyzed.

\section{MATERIALS AND METHODS}

The experiment was started in April 2013 and was carried out in Eger (Hungary) and settlements in September 2013. The seeds were sown on February 10, 2013 into plant trays, into glasshouse. The sawing method was based on the description of LARSON (1992).

The seedlings of 3-4 leaf stage were potted into $2 \mathrm{dl}$ pots on April 29, 2013 and subsequently moved to open ground conditions under raschel net. Treatment groups established are shown as follows:

- Control

- Regalis WG $(0,25 \%$ concentration)

- Toprex $(0,1 \%$ concentration)

- Caramba SL $(0,1 \%$ concentration)
- Chlorocholine chloride $(0,1 \%$ concentration $)$

- Cultar $(0,1 \%$ concentration)

The retardants were applied by hand sprayer onto the plants, approximately 10 days intervals.

The measurements were performed weekly according to the following criteria:

- plant height (from the surface of the growing medium of the plant apex in $\mathrm{cm}$ )

- plant diameter (widest diameter of the plant bush in $\mathrm{cm}$ )

- leaf number (total number of leaves)

The chlorophyll content was determined with spectrophotometer at the end of the treatment according to Shannon et al. (1966). Five samples were measured per treatment, data were appreciated statistically with PASW 18.

\section{RESULTS AND DISCUSSION}

Overall, the majority of species investigated for the Regalis and the application Cultar generated the most impact. The plants were treated with these habits bushier, had more leaves, flowers, than the control plants. The dwarfing prolonged culture time of flowering started 10-14 days later than in the control group. Since the effect of drugs of species observed, further studies are needed to determine the optimal concentrations and times.

By Matthiola incana the Caramba SL $(924,6$ $\mu \mathrm{g} / \mathrm{g})$ and the Toprex $(944,4 \mu \mathrm{g} / \mathrm{g})$ did not reduce significantly the chlorophyll content of the measured leaves, compared with the Control $(948,9 \mu \mathrm{g} / \mathrm{g})$.

However by the effect of the CCC $(850,9 \mu \mathrm{g} / \mathrm{g})$ and the Cultar $(883,2 \mu \mathrm{g} / \mathrm{g})$ significant reducing was noticed. There are not significant different between the effect of the two product. The

\section{Chlorophyll content on Matthiola}

\section{incana}

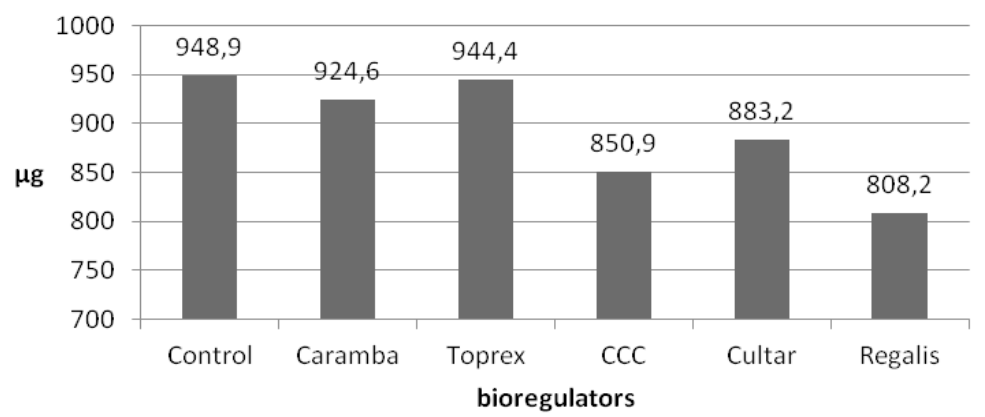

Fig.1. Chlorophyll content on Matthiola incana 


\section{Chlorophyll content on Scabiosa}

atropurpurea

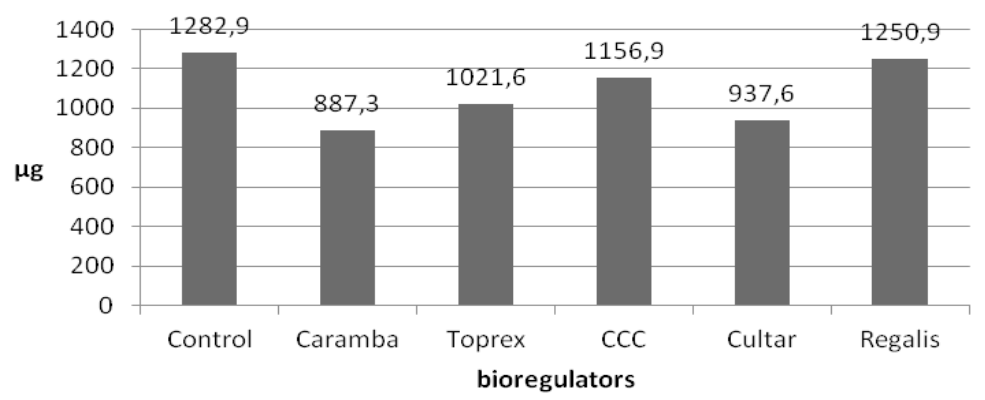

Fig. 2. Chlorophyll content on Scabiosa atropurpurea

Tab. 1. Results of measurements on Scabiosa atropurpurea

\begin{tabular}{cccc}
\hline \multicolumn{4}{c}{ Scabiosa atropurpurea } \\
\hline $\begin{array}{c}\text { Avarage weight } \\
(\mu \mathrm{\mu g} / \mathrm{g} \\
\text { Bioregulator } \\
\text { fresh weight) }\end{array}$ & $\begin{array}{c}\text { Deviation } \\
\mathbf{( \mu g} / \mathrm{g} \\
\text { fresh weight) }\end{array}$ & $\begin{array}{c}\text { Statistic } \\
\text { result }\end{array}$ \\
\hline Control & 1282,94962 & 141,2626419 & $\mathrm{a}$ \\
\hline Regalis & 1108,689754 & 232,7983188 & $\mathrm{ab}$ \\
\hline Caramba & 887,2636104 & 187,7768174 & $\mathrm{~cd}$ \\
\hline Toprex & 1021,658514 & 88,27434518 & $\mathrm{~cd}$ \\
\hline CCC & 1156,895878 & 122,1134567 & $\mathrm{~b}$ \\
\hline Cultar & 937,5634398 & 58,98888003 & $\mathrm{~d}$ \\
\hline
\end{tabular}

application of Regalis WG $(808,2 \mu \mathrm{g} / \mathrm{g})$ resulted additional significant reducing compared to all four treatment. The effect of this letter retardant can be perceived visually, too, but this can be a degrading factor by the treatment. So all the tested regulators are suitable for retarding the growth of Matthiola incana, except of Regalis WG by the effect on the chlorophyll content.

In the case of Sabiosa atropurpurea the chlorophyll content of leaves did not reduce significantly due to Regalis WG compared to the Control $(1282,9 \mu \mathrm{g} / \mathrm{g})$ values. The Toprex $(1021,6$ $\mu \mathrm{g} / \mathrm{g})$ and the CCC $(1156,9 \mu \mathrm{g} / \mathrm{g})$ significantly decreased the chlorophyll content comparing to the Control group, but these values are not differ significantly to the values, which are generated during the measurement with Regalis WG. The lowest chlorophyll contents were measured by Cultar (937,6 $\mu \mathrm{g} / \mathrm{g})$ and Caramba SL (887,3 $\mu \mathrm{g} / \mathrm{g})$. The values obtained are significant different from the effect the Control, the Regalis WG and CCC, but
Tab. 2. Results of measurements on Matthiola incana

\begin{tabular}{cccc}
\hline \multicolumn{4}{c}{ Matthiola incana } \\
\hline Bioregulator & $\begin{array}{c}\text { Avarage weight } \\
(\boldsymbol{\mu} / \mathbf{g} \\
\text { fresh weight) }\end{array}$ & $\begin{array}{c}\text { Deviation } \\
(\boldsymbol{\mu g} / \mathbf{g} \\
\text { fresh weight })\end{array}$ & $\begin{array}{c}\text { Statistic } \\
\text { result }\end{array}$ \\
\hline Control & 948,9103022 & 80,75623 & $\mathrm{a}$ \\
\hline Regalis & 808,2108002 & 31,08589 & $\mathrm{c}$ \\
\hline Caramba & 924,5867037 & 68,29432 & $\mathrm{a}$ \\
\hline Toprex & 944,4342879 & 83,68505 & $\mathrm{a}$ \\
\hline CCC & 850,948008 & 64,21846 & $\mathrm{~b}$ \\
\hline Cultar & 883,1997358 & 58,41599 & $\mathrm{~b}$ \\
\hline
\end{tabular}

compared to the Toprex there is not any significant difference.

\section{CONCLUSION}

Summarizing the chlorophyll content of the leaves of the tested plants was reduced by using growth retardants. The rate of decrease depended on the regulator type. The effect of the retardants were not the same on the tested species, the change was not proportional too, so the effect of the retardants is species-specific. By cultivation for market is mandatory to test the retardants before use.

\section{REFERENCES}

1. Băla Maria, Berecici DN (2009). The treatment effect of Cycogan on the growing and flowering on some species of Pelargonium genus. Journal of Horticulture, Forestry and Biotechnology 13:406-409.

2. Basra AS (ed.) (2000). Plant Growth Regulators in Agriculture and Horticulture. Food Product Press Inc. New York, London. p. 89-130. 
3. Gomez J, Sánchez-Martínez D. Stiefel V, Rigau J (1988). A gene induced by the plant hormone abscisic acid in response to water stress encodes a glycine-rich protein. Nature, 334. p. 262-264.

4. Ikeda, A, Uegechi-Tanaka M, Sonoda Y, Kitano H, Koshioka M, Futsuhara Y, Matsuoka M, Yamaguchi M (2001). Slender rice, a constitutive gibberellin response mutant is caused by a null mutation of the SLR1 Gene, an ortholog of the 58 height-regulating gene, GAI/RGA/RHT/D8. .American Society of Plant Biologists, 13. 5. p. 999-1010.

5. Mansour HA, El-Maadawy EI, Othman IZ (2010). Production of sunflower, helianthus annuus L., as a flowering pot plant using different potting media and growth retardant treatments. The Bulletin of Faculty of Agriculture Cairo University. p. 33-34.

6. Reiners, S. (2007). Hemmstoffe bei Topfranunkeln: AlarErsatz gesucht. Gärtnerbörse 12 p. 26-28.

7. Richter, M. (2006). Hortensien mit frühem Regalis-Einsatz hemmen. Gärtnerbörse 5 p. 46-49.

8. Ueber E (2007). Hemmstoff-kombinationen und Spritzbrühemengen. Gärtnerbörse 2 p.40-42.

9. Ruttensperger U, Koch R (2005). Sparrige Angelonien mit Hemmstoffen kompakt halten Gärtnerbörse 1 p. 34-35.

10. Shannon, L.M., Kay, E., Lew, J.R. 1966. Peroxidase Isozymes from Horseradish Roots. J. Biological Chemistry 241: 9 2166-2172. 